\title{
下顎則方偏位症例における機能珓合の獲得について
}

\author{
高階博文 ${ }^{1)}$, 寺田香織 ${ }^{2)}$, 青木 聡 $^{3)}$, 佐藤貞雄 ${ }^{11}$
}

\section{Achieving Functional Occlusion in Cases of Mandibular Lateral Deviation}

\author{
Hirofumi Takashina, Kaori Terada, Satoshi Aoki, Sadao Sato
}

\begin{abstract}
Many cases of mandibular lateral deviation in adults, while having contributory factors such as malalignment of teeth and poor dental habits during the development stage of a normal lifestyle, are believed to be the result of adaptations made to activate the stomatognathic function as fully as possible.
\end{abstract}

Conversely, in addition to the primary functions of functional occlusion such as mastication, speech, respiration, esthetics and maintaining posture, some also advocate the function of stress management through bruxism. Recently, various dynamic adaptation strategies of the body to stress are reported to be relieved through the process known as allostasis, and it has been suggested that maintenance of allostasis in the body is a further function of occlusion.

The treatment of mandibular lateral deviation can be achieved with a total jaw occlusion reconstruction, combining corrective treatment with crown restoration / crown prosthesis treatment. Through corrective treatment, the mandibular position can be easily changed, although the skeletal morphology is difficult to change. Further, while the occlusal plane, tooth configuration, and tooth axis can be altered through corrective treatment, crown configuration does not change. The existence and degree of problems associated with each of these aspects must therefore be accurately understood, and it is necessary to perform treatment that considers the body's adaptation response.

成人の下顎側方偏位症例の多くは，成長発達期に歯列不正や悪習癖などの誘因を抱えた まま日常生活を営むなか，顎口腔系の機能を最大限発揮させられるように適応した結果生 じた不正咬合だと考えられる。

機能咬合の獲得は, 咀嚼, 会話, 呼吸, 審美, 姿勢維持などの本来の機能に加え, ブラ キシズムによるストレスマネージメントが加えられた考え方が提唱されている。近年，生 体の持つストレスに対するさまざまな動的適応反応は, アロスタシスという概念でとらえ られ，咬合が生体のアロスタシスを維持する機能を持つと示唆されている.

下顎側方偏位症例の治療は, この2つの課題を, 矯正治療, 歯冠修復・歯冠補緅治療を 組み合わせ，全顎的な咬合再構築を行うことにより，獲得することとなる．

治療に際しては, 矯正治療によって変化の起こりやすい下顎位, 矯正治療によって変化 の起こりにくい骨格形態，矯正治療によって変化する咬合平面，歯列形態，歯軸，矯正治 
療によって変化しない菌冠形態, これらそれぞれの問題点の有無と程度を的確に把握して, 生体適応反応を考虑した治療を行うことが重要である。

Key words : 下顎側方偏位 Mandibular Lateral Deviation, 機能咬合 Functional Occlusion, アロスタシス Allostasis, ブラキシズム Bruxism, ストレスマネージメン ト Stress Management

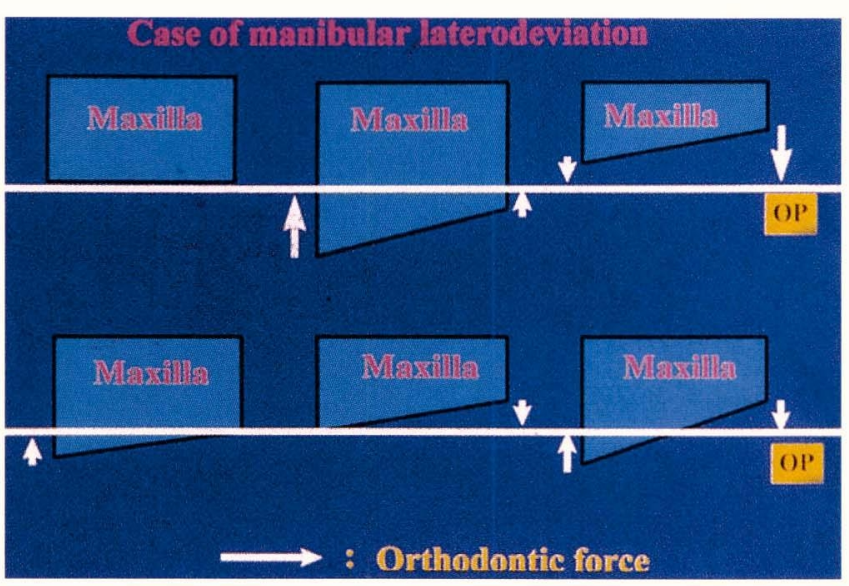

図 1 上顎咬合平面の左右差を示す模式図.

\section{はじめに}

下顎側方偏位症例は，顔面正中に対しオトガイが左右的 に偏位しているもの，と定義されている。抄もな成因は， 不正咬合による早期接触，悪習癖，ポステリア・ディスク レパンシー ${ }^{1}$ ，不良な歯科治療，㖽関節症，遺伝，外傷な どである。成人の下顎側方偏位症例の多くは，成辰発達期 に歯列不正や悪習癖などの誘因を抱えたまま日常生活を営 むなか, 顎口腔系の機能を最大限発揮させられるように適 応した結果と考えられる。下顎側方偏位によってもたらさ れる障害は, 顔貌の不調和などの憲美的障害, 咀嚼障害や 顎関節症などの機能的障害，番美的障害や顎位の不調和に ともなう心理的障害が挙げられる².

このような障害をもつ症例を診察するには, 頭蓋骨や上 下顓骨の变形, 咬合高径の左右差, 咬合平面の左右差, 歯 や歯数の異常, 機能的障害の有無, 審美的障害の程度, 患 者の生活背景等を把握する必要がある。下顎側方偏位は, 上顎の咬合平面に問題を抱え，上頡骨が歪んでいる場合が 多数見受けられる。咬合平面と咬合高径の問題点は，模式

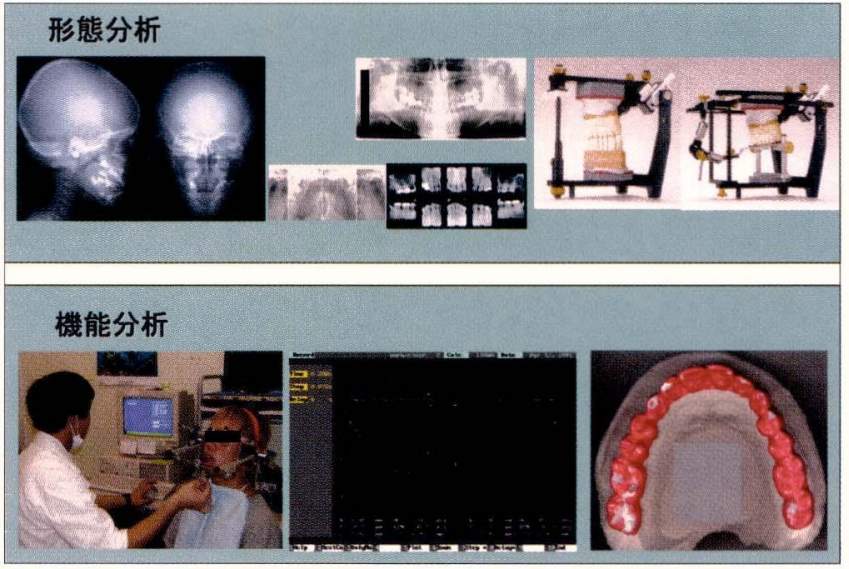

図2 診断のために採取する資料。

的に示すと（図１）, 咬合平面に対し歯が高位にあり左右 差があるもの，低位にあり左右差のあるもの，片側のみ高 位なもの, 片側のみ低位なもの, 片側は高位で片側は低位 なものに分けられる2. 下顎側方偏位の病態を的確に把握 するための診断資料として，われわれはパントモ，デンタ ル, TMJ4分割, 正貌側貌セファロ, 顎機能検査, 咬合器 付着模型，ブラックスチェッカーを採得している(図2).

不正咬合によるい腔機能障害は, う蝕発生の誘因, 歯周 疾患の誘因, 外傷および柬根吸収の誘因, 咀嚼機能障害, 筋機能異常，顎骨の成長障害，発音障害，心理的障害なと が挙げられる。機能咬合の獲得は, これらの機能障害を改 善させ, 咀嚼, 会話, 呼吸, 審美, 姿勢維持などの本来の 機能を確立することである。近年，機能咬合の役割の1つ として，ブラキシズムがストレスマネージメントの作用を 持つという考え方が提唱されている年.

これまでブラキシズムは，歯や歯周組織の破壊を来すこ とから恵習慣として扱わ机てきた。しかしこれまでの研究 によりストレスマネージメントとしての機能を持つことが 明らかとなってきた 


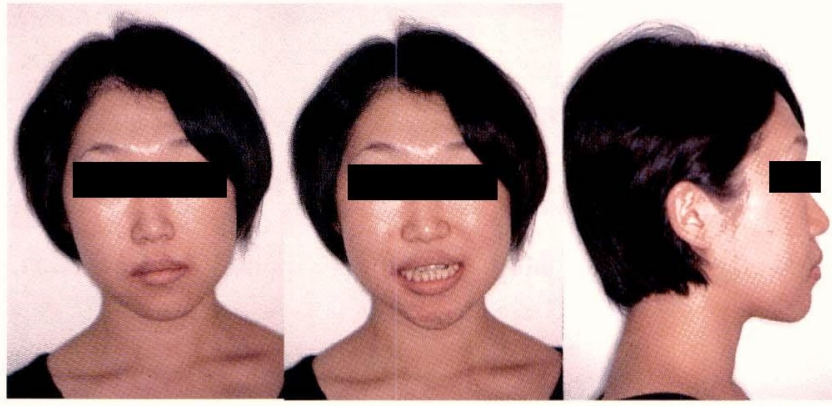

図3 術前顔貌所見

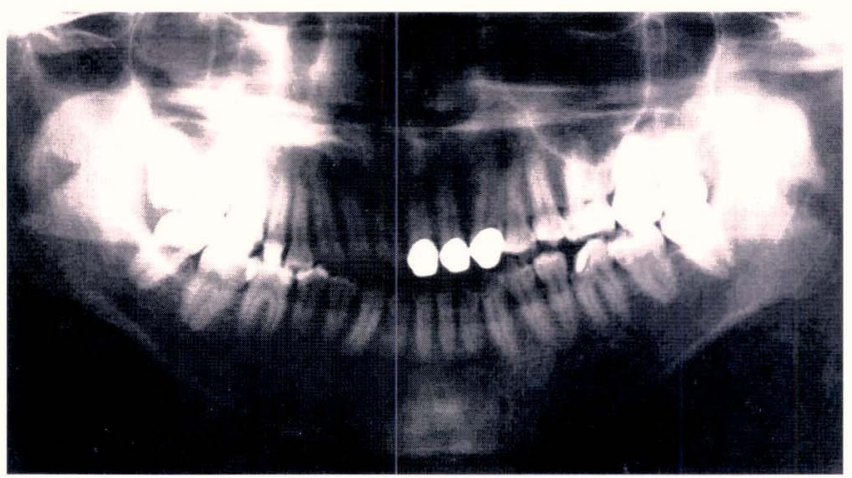

図 5 術前パノラマX線写真.

また最近では, ストレスと生体反応を理解する新しい概 念としてアロスタシス（allostasis）という考え方が提唱ざ 机てるる ${ }^{19-211}$ ・アロスタシスの定義は，ストレッサーとい う外的あるいは内的な環境压力に対して, 生体の情報伝達 系と連携して自律神経系, 神経内分泌系, および免疫系が 反応し, 生体の安定性を維持しようとする適応变化である. アロスタシスは局所のホメオスタシス維持を補助する全身 的反応と理解されている。これまでの研究によりブラキシ ズムによるストレスマネージメントが, 咀嚼器官の重要な 機能であることが示されてきている。機能咬合の獲得は, 顎口腔系の安定にとって重要であるとともに, ストレスに 対するアロスタシスの維持にとっても重要と考えられてい $ろ^{22}$.

不正咬合の治療は, この2つの課題を, 矯正治療, 歯冠 修復・歯冠補緅治療を組み合わせ，全顎的な咬合再構築を 行うことにより獲得することとなる。顎口腔系の適応する 生理的な下顎位に咬合平面や咬合高径をコントロールさせ ることで誘導し，歯列を配列させ，ブラキシズムを考慮し たガイダンスを歯軸のコントロールや歯冠形態の修正・修 復によって獲得しなけ机ばならない。加えて下顎側方偏位 症例では，骨格形態の変形をともなう場合も多く，硈偏位 の改善や正中線の一致などの審美的要素も要求される.

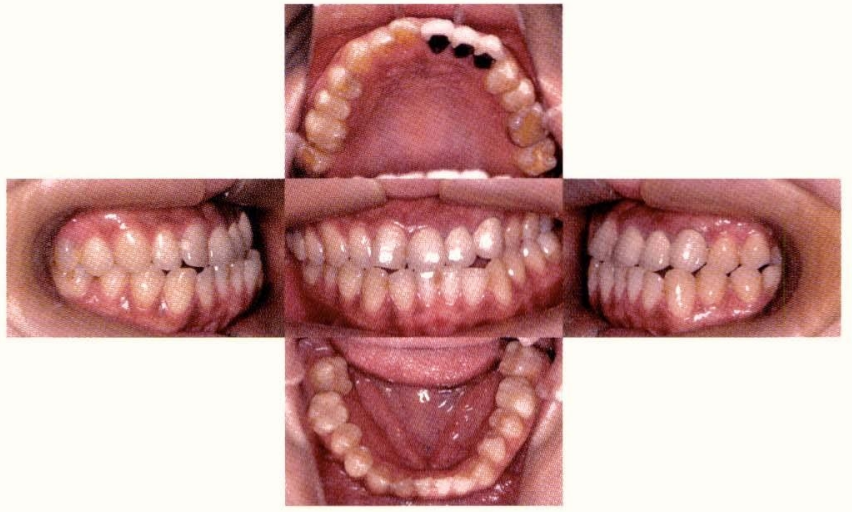

図4 術前口腔内所見.

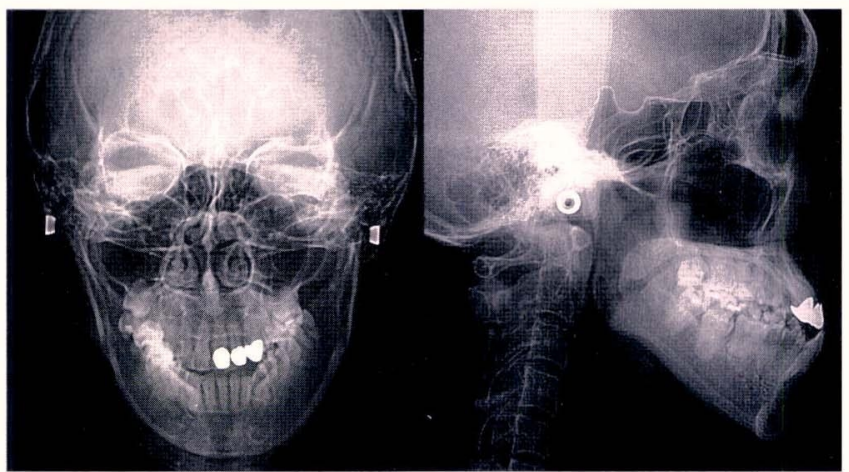

図6＼cjkstart術前正貌及び側貌セファロ写真

本稿では，下顎側方偏位症例における機能咬合の獲得に あたり，下顎位や咬合平面，歯軸やガイダンスなどの変化 と適応現象を観察しながら治療をおこなった2症例につい て考察する。

\section{症例}

症例1：顎機能障害をともなった下顎側方偏位症例

I. 初診時所見

患者：25歳 11 力月，女性.

主訴：咬み合わせが悪く，顎が曲がっているのを治した いが手術は絶対にしたくない.

既往歴，家族歴：ともに特記事項なし

顔貌所見：正面観では左右非対称でオトガイが左方に偏 位しており，側面観ではstraight type 呈している。また オトガイの偏位にともなって頸部の湾曲もみられる（図 3).

口腔内所見：左右ともにアングル III級咬合，右側第二大 臼歯のシザースバイトならびに左側荗部でのクロスバイ 卜がみられ下顎は左方偏位している。また，オーバージェ ット $0 \mathrm{~mm}$ ，オーバーバイト $0 \mathrm{~mm}$ でオープンバイト傾向を 呈している(図4).

X線写真所見：上下左右第三大臼歯，う蝕歯。靧関節パ 


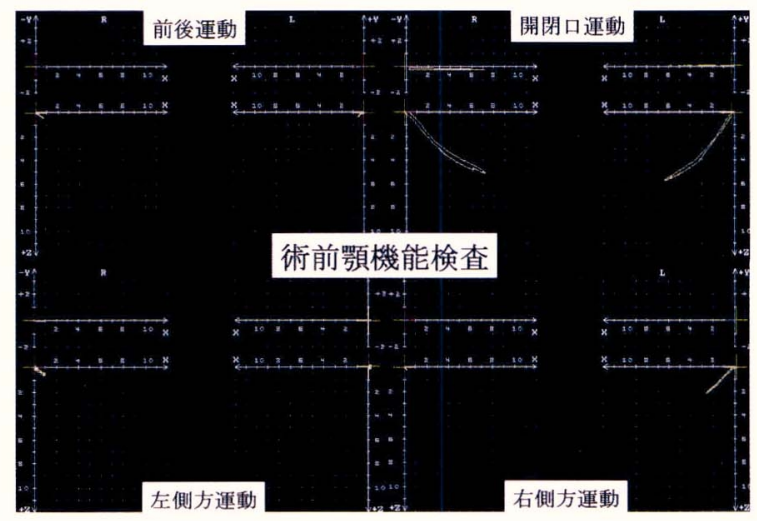

図7 術前㓵機能検査

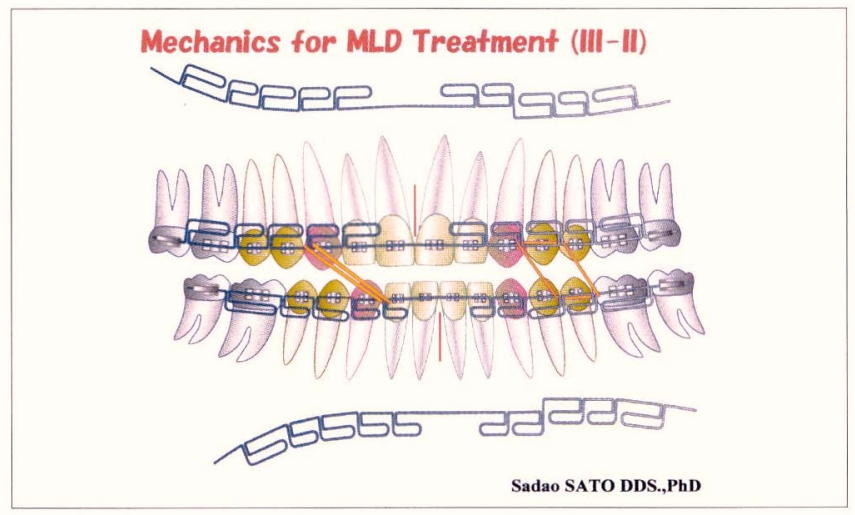

図 9 下顎側方偏位症例治療時における MEAW の調整.

ノラマ写真所見では，左右下顎頭長径に違いをみとめ，下 顎頭の変形は少ない(図5).

セファロ写真分析所見：正貌セファロでは上顎左側第一。 大的歯が低位で咬合平面は左上がりである。下顎は頭蓋に 対し左方に偏位している。側貌七ファロでは骨格性四級傾 向および開口傾向である(図6).

顎機能検査 (CADIAX) 所見：前後運動, 開閉口運動, 左側方運動, 右側方運動の基本4運動において連動量が低 下している(図7).

歯科症状以外の所見：頸部と肩部の筋痛がみられる。

\section{II．プロブレムリストおよび治療目標}

下顎左方偏位，右側第二大妇菊シザースバイト，左側臼 歯部クロスバイト，ポステリアディスクレパンシー，顎関 節運動障害，骨格性且級，開咬傾向，う蝕が問題となる。 な扮患者は以前，某歯科大学矯正科や矯正専門医に扔い て, 外科的矯正治療を併用した治療方針を提案されていた。 治療目標は生理的下顎位での機能咬合の確立である。

\section{III. 治療経過}

上下左右第三大妇歯の抜歯後，MBA を装着しレベリン 夺開始。動的治療開始 12 力月目に, 下顎左方偏位改善

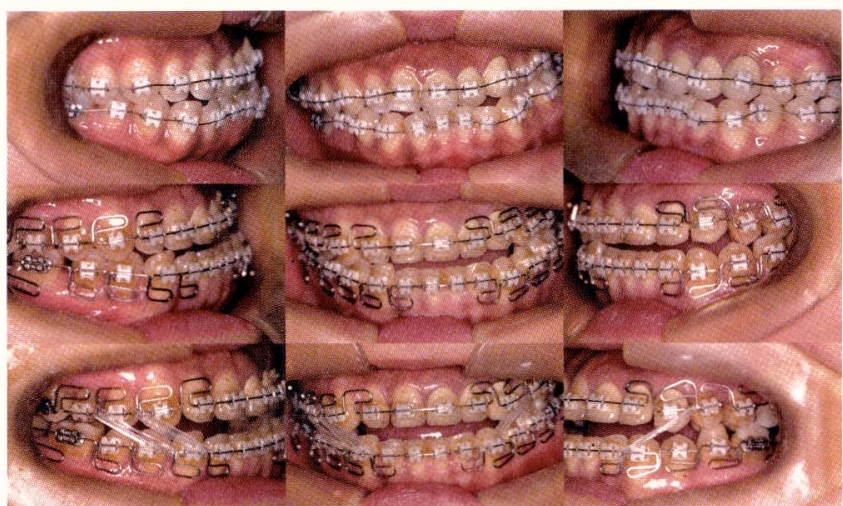

図8 矯正治療開始か50 力月 (上), 12 力月 (中), 15 力月 (下).

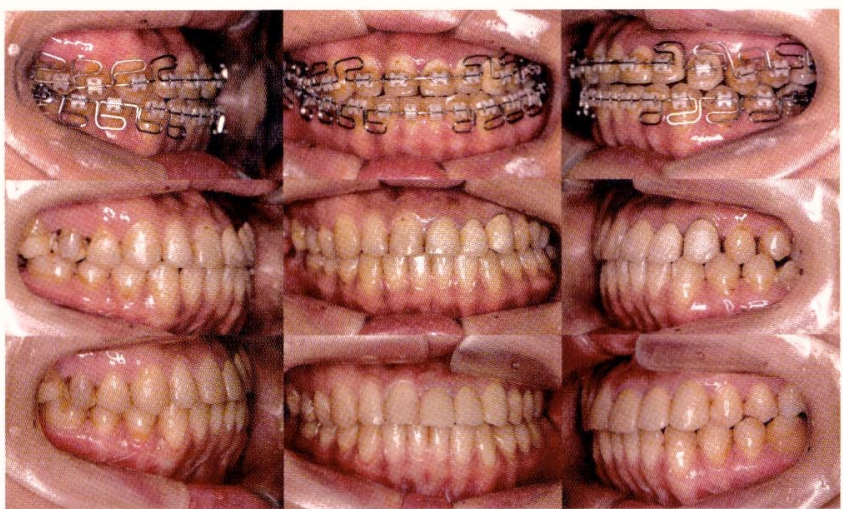

図 10 矯正治療開始から24 力月 (上)，39 力月 (中)，48 力月 (下)

のため右側にTip-back bend 左側にStep-up bendを施した multiloop edgewise archwire (MEAW) を上下に装着した (図 8)。右側ではShort class III elastics 在左側ではShort class II box form elastics 老使用した（図9）。治療の進行に 合わせ，左側では暫間的に臼歯咬合面をコンポジットレジ ンにより咬合挙上させながら非接触歯の挺出を行った。挙 上を行った歯は、非接触歯の咬合接触が得られた段階で, 随時削合し挺出させるように調整した。

動的治療開始 24 力日旦は，およそ上顎前歯1本分あっ た正中のずれもかなり改善してきていた。動的治療の終盤 では, relapse考慮してややovercorrectionを行い，下顎位 や歯軸の安定をはかる日的でpassiveに調整したレクタンギ ユラーワイヤーを装着し，テンポラリークラウンの形態修 正を行い咬合関係の適応を観察した。矯正装置除去後，約 6 力月の保定期間を拈き歯冠修復，歯冠補緅処置を行った. 治療期間は合計で約48力月であった（図 10).

\section{N. 治療終了時所見}

顔貌所見：正面観でオトガイの左方偏位は見られるが， 初診時に比較し改善していた。また頸部の湾曲も改善して いた (図 11 ).

口腔内所見：歯の近遠心的位置および煩舌的な歯軸の改 


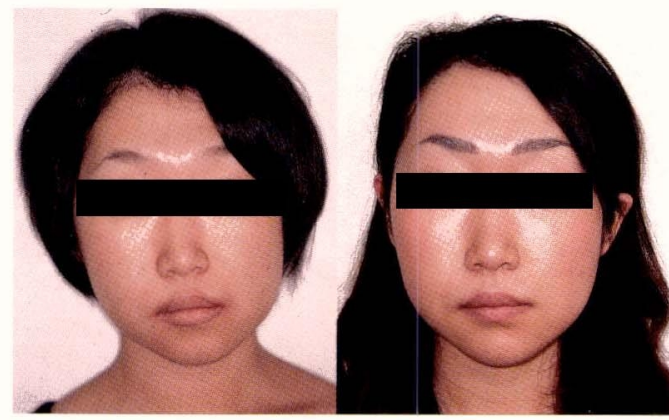

図 11 術前（左）術後（右）顔貌所見比較.

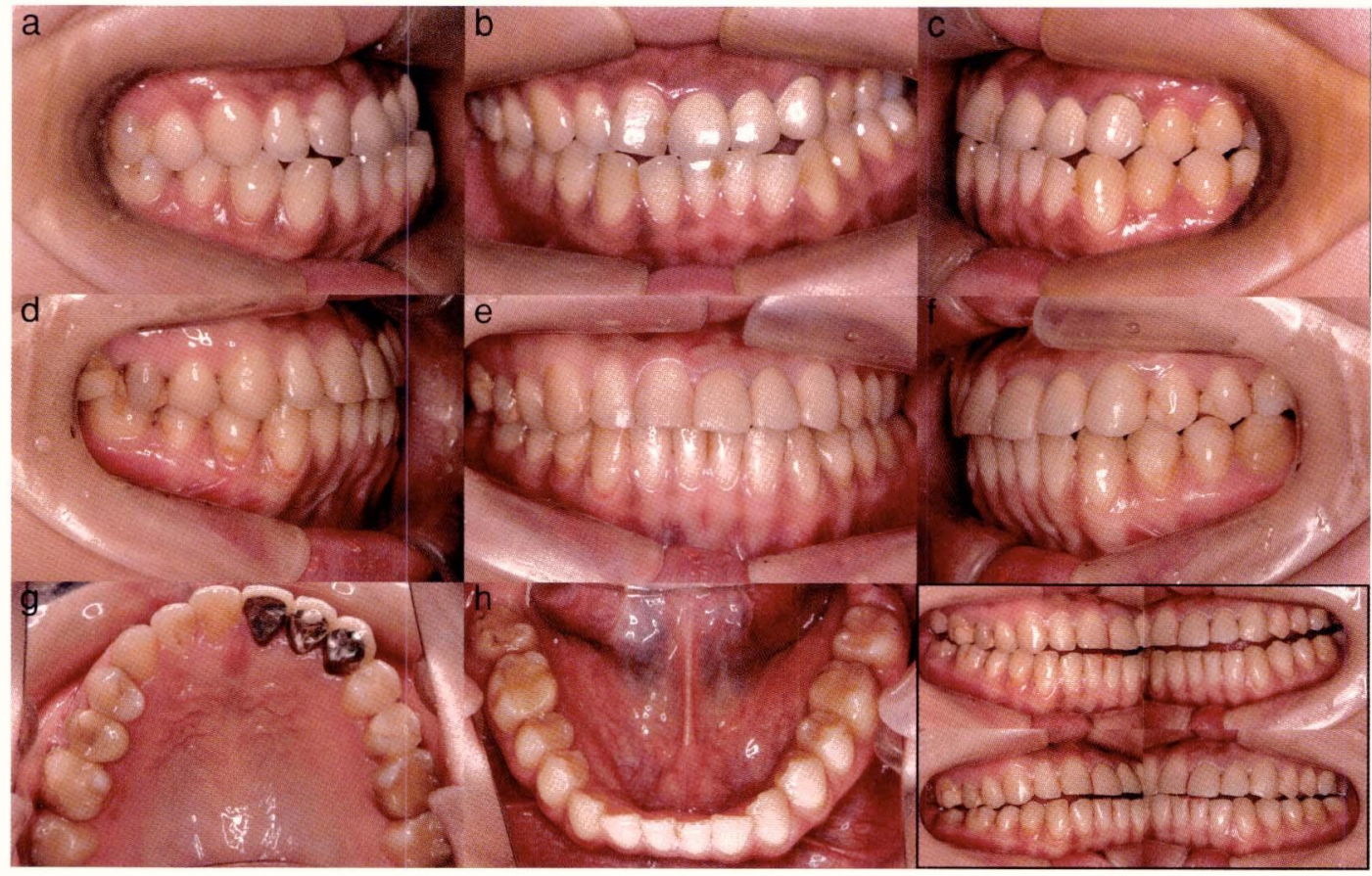

図 12 術後口腔内所見 a-c :術前, d-h : 術後, 枠内：術後側方ガイダンス。

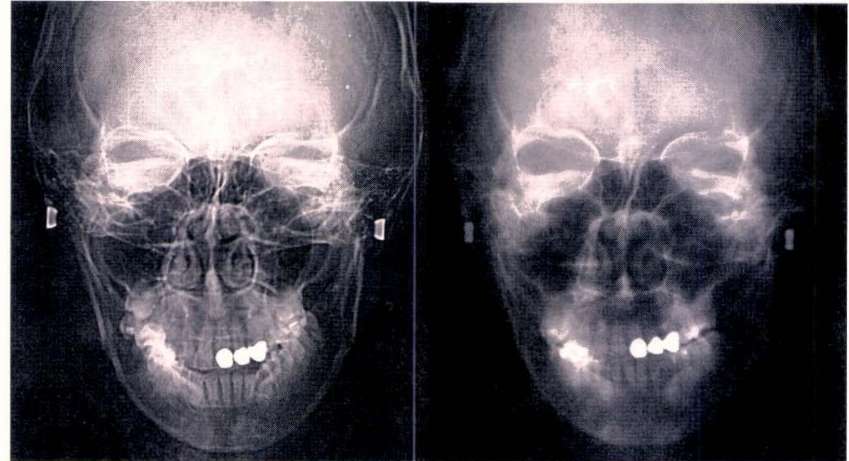

図 13 術前（左）術後（右）正貌セファロ写真比較.

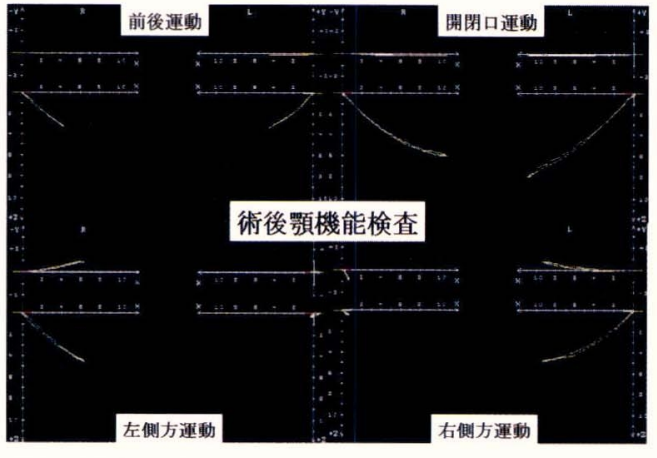

図 14 術後顎機能検査
善が羿められ，咬合関係もI級関係に近づいていた。また 正中のずれも初診時と比較して改善し，およそ下顎の前歯 半㐘分となった。初診時では開口傾向であったため, 側方 連動時に大臼歯がガイドし, 均衡接触も見られていたが, 治療終了時では側方運動時のガイドが確立され，均衡側で の離開も獲得できた（図12）.

X線写真所見：㐘根吸収などはなく, 㐘軸の改善がみら
れた。

セファロ写真分析所見：正貌セファロにおいて，下顎の 左方偏位の改善を認めた。側貌セファロでは大きな変化は みられないものの，開口は消失した（図13）.

顎機能検査 (CADIAX) 所見：前後運動，開閉口運動, 左側方運動，右側方運動の基本4連動において運動量が回 復した（図 14). 
図 15 術前顔貌所見.
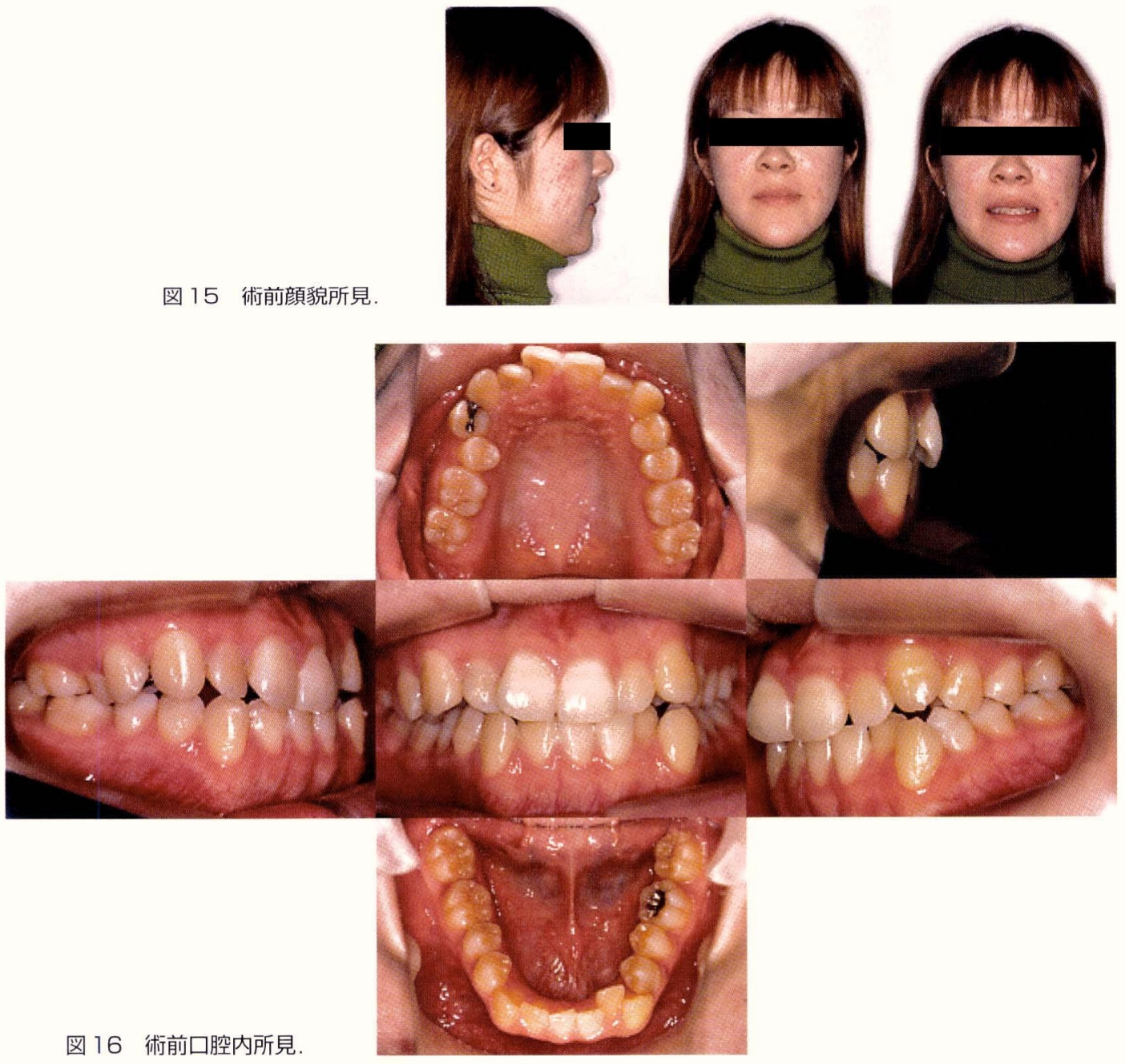

図 17 術前パノラマX線写真.

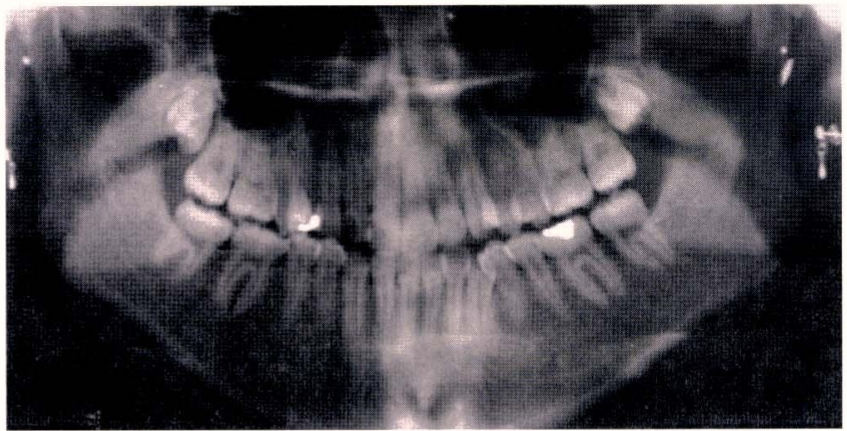

歯科症状以外の所見：頸部と肩部の筋痛は消失した。

\section{症例2：顎機能障害をともなわない下顎側方偏位症例}

\section{I．初診時所見}

患者：18歳10 力月, 女性.

主訴：顎が左に曲がっていて中心がずれているうえ，歯 並びが悪いので治したい．

既往歴，家族歴：ともに特記事項なし

顔貌所見：正面観では左右非対称でオトガイが左方に偏 位しており，側面観ではstraight typeを呈している（図 15）。
口腔内所見：左右ともアングルＩ級咬合，上下前歯・小 臼歯部に叢牛が存在し，上下正中線は不一致である。また 歯列弓形態も左右非対称である。とくに下顎左側小臼歯は 強い舌側傾斜がみられる。前蔽部の被蓋関係はオーバー ジェット $3 \mathrm{~mm}$ ，才ーバーバイト $2 \mathrm{~mm}$ である (図 16).

$\mathrm{X}$ 線写真所見：上顎左右第三大自歯が存在している。う 蝕などはなく歯周組織も良好で，下顎頭の変形もみられな い(図 17).

セファロ写真分析所見：正貌セファロに扔いて Frontal occlusal plane と煩骨前頭縫合平面は，ほぼ平行で上顎の咬 

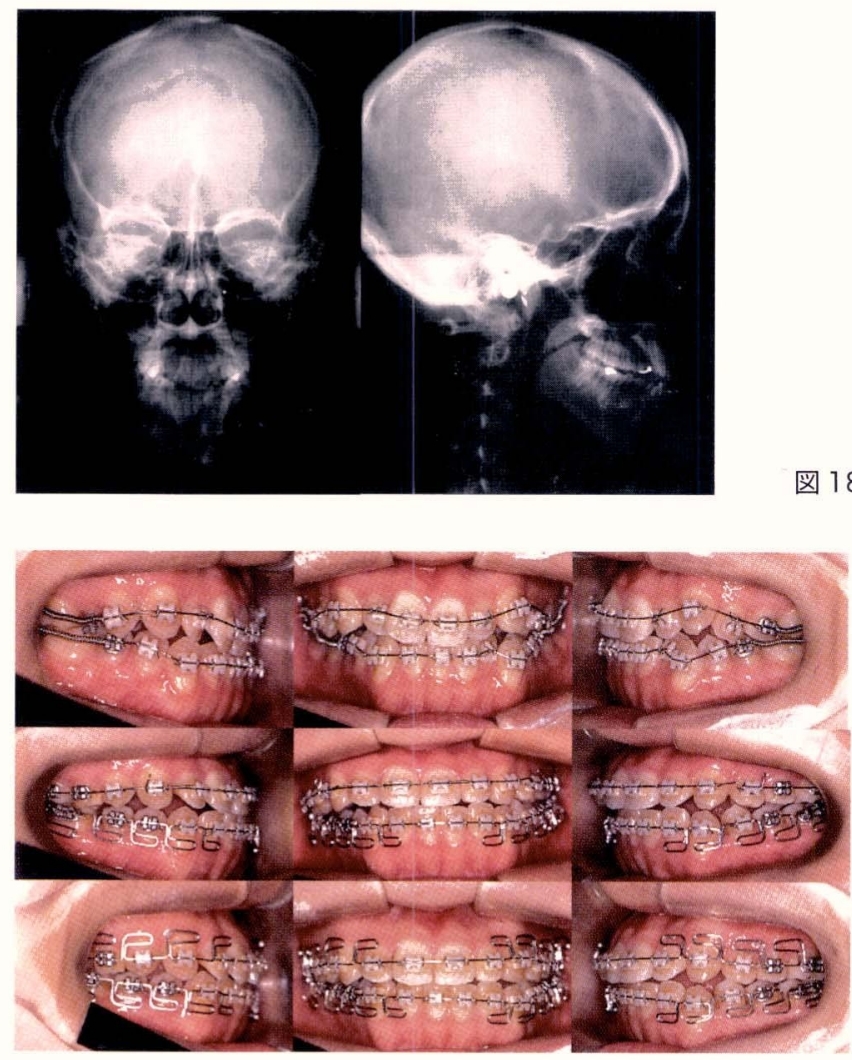

図 19 矯正治療開始から口 力月後 (上), 5 力月後 (中), 7 力月後.
図 18 術前正貌及び側貌セファロ写真

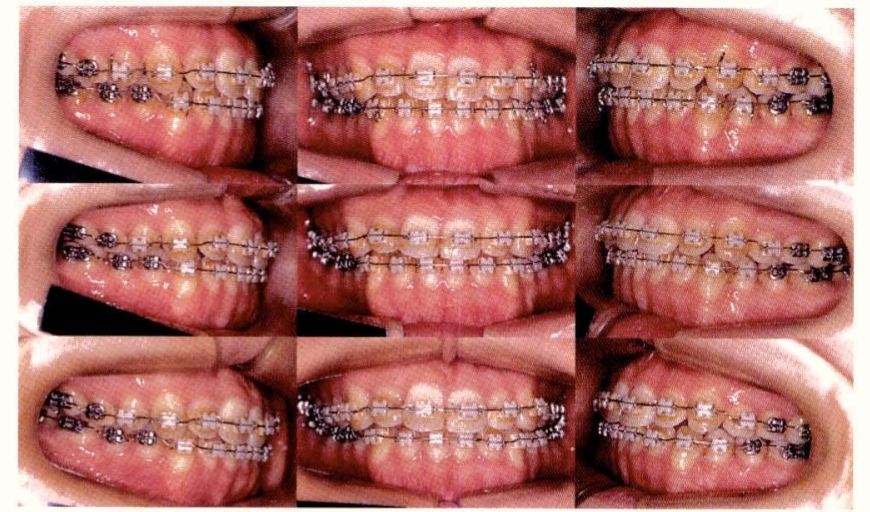

図20 矯正治療開始か518 力月後 (上)，20 力月後 (中), 23 力 月後 (下).

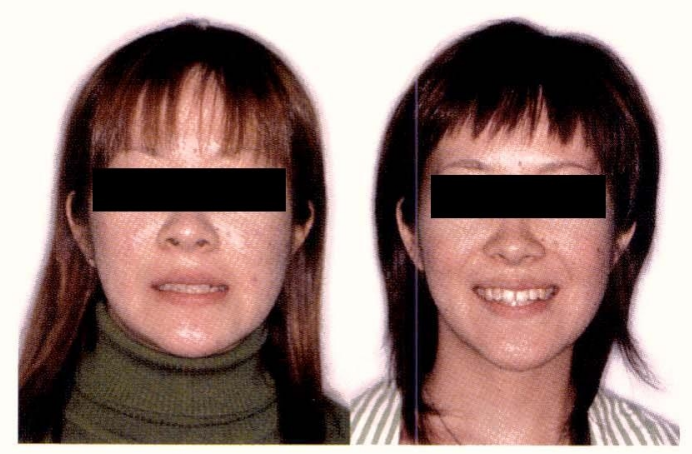

図21＼cjkstart術前（左）術後（右）顔貌所見比較.
合平面に異常はみられない。下顎は頭蓋に対し左方に偏位 している。側貌セファロでは著明な骨格的不正は認められ ない(図 18).

顎機能検査 (CADIAX) 所見：矢状顆路傾斜角は右 $57.0^{\circ}$ ，左 $48.0^{\circ}$ であり，とくに異常所見は認めない.

\section{II．プロブレムリストおよび治療目標}

右側小臼歯部叢生による咬頭干涉，左側臼歯部舌側傾斜 による咬合高径の左右差，下顎の左方偏位が問題となる. 治療目標は生理的下顎位での機能咬合の確立である.

\section{III. 治療経過}

上顎左右第三大臼歯の抜歯㣪，MBAを装着しレベリン
グを開始。動的治療開始 5 力月月に, 下顎にmultiloop edgewise archwire (MEAW) を装着した。7カ月日には, 下顎左方偏位改善のため右側にTip-back bend 左側にStepup bend 施したmultiloop edgewise archwire (MEAW) を 上下に装着した。右側ではShort class III elasticsを左側では Short class II box form elastics 使用した（図 19)。治療の 進行に合わせ，左右の咬合平面や咬合高径が変化するとと もに，前歯部に表れてくる反作用老調節した。動的治療開 始 17 力月目では, 上下顎正中線もほぼ一致する状態とな つた。動的治療開始 18 力月目には，下顎位や歯軸の安定 をはかる目的で passiveに調整したラウンドワイヤーにサイ ズダウンさせた。咬合関係の適応老観察したところ，下顎 位はわずかに左方へシフトした。約 6 力月間の観察後, 安 


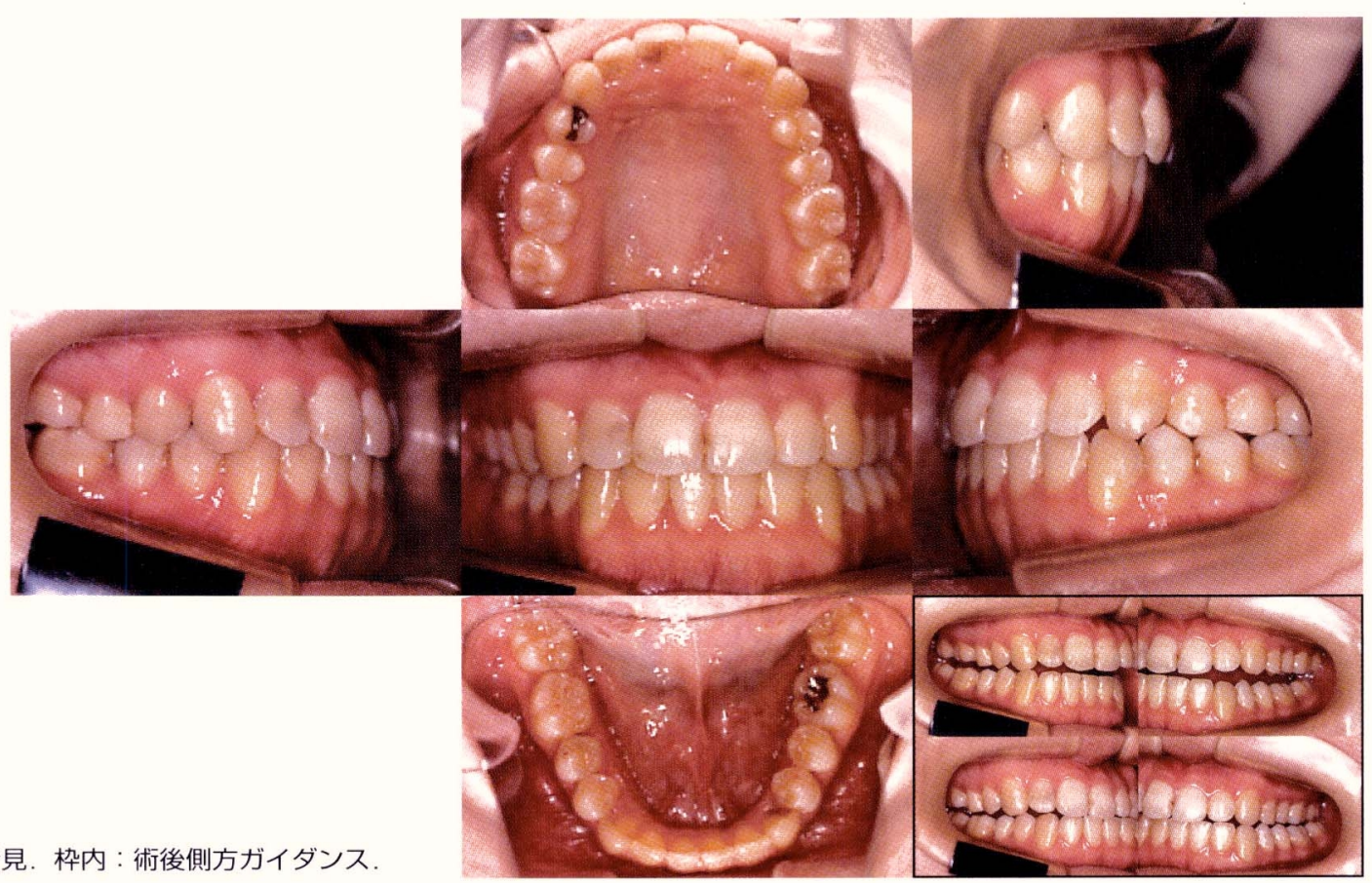

図22 術後口腔内所見. 枠内 : 術後側方ガイダンス.

図23術前術後正貌重ね合わせ (術前：黑線，術後：赤線).

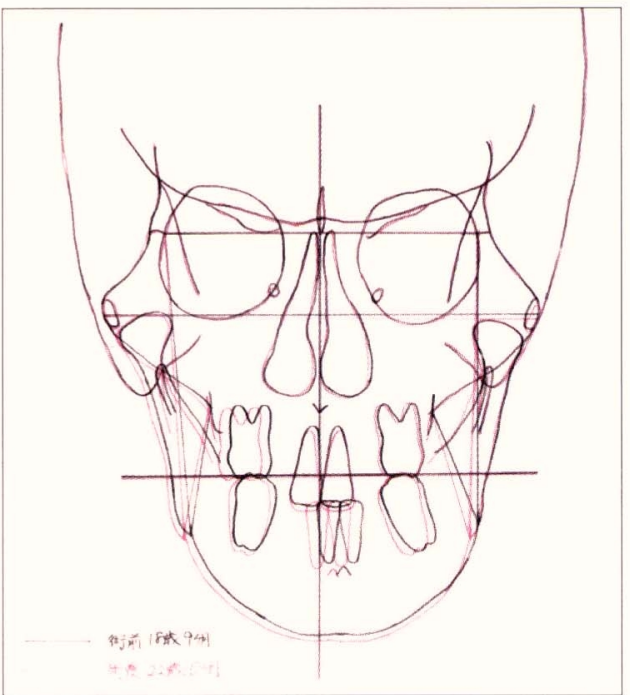

定が得られたと考え矯正装置を撤去した（図20）。

\section{IV. 治療終了時所見}

顔貌所見：正面観ではややオトガイの左方偏位は見られ るが，初診時に比較し改善していた。また口唇周囲の調和 が得られた（図21）。

口腔内所見：歯列弓は拡大し柬は再配列され，上下正中 線はやや左にシフトしているものの術前に比較し改善され た. 左側方運動時の離開量は少ないが, 機能咬合は獲得で きた（図22）.

X線写真所見：歯根吸収などはなく，歯軸の改善がみら れた。

セファロ写真分析所見：正貌セファロにおいて，下顎の
左方偏位の改善を認めた（図23）。側貌セファロでは大 きな変化はみられなかった。

顎機能検査（CADIAX）所見：とくに著変はなく良好な 状態である。

\section{考察}

\section{症例 1}

本症例の治療に扔ける特徵は，下顎側方偏位の非外科的 治療に打いて矯正治療と歯冠補綴治療を組み合わせ，機能 咬合を確立させた点である。

この症例は術前の正貌セファロ所見からも，下顎の偏位 量も多く下顎頭長径に左右差を認め, 骨格の歪みも大きい. しかし，主訴にもあるように，患者は外科的矯正治療を拒 
否しており，骨格の歪みに対しては大きな改善は望めない 状況であった。この場合，矯正治療により改善の期待でき る歯列弓形態，咬合平面，咬合高径をコントロールするこ とにより下顎位を変化させ，顎偏位の改善を図ることとな る．上顎第一大白歯は左側が低位のため咬合平面は左上が りであり，適応可能な生理的下顎位も咬頭勘合位よりは右 側と考えられた。矯正治療においては，上顎左側を積極 的に挺出させることによって咬合平面の左右差の改善をは かり, 偏位側での咬合挙上と非偏位側での圧下を行った。 咬合挙上に関しては，暫間的なコンポジットレジンを用い 挙上させ, その間に離開している歯を挺出させ咬合させた. 後に，レジンを削合し該当歯を挙上させ咬合させた。これ は，長径に左右差のある下顎頭が日常機能を営むなかで矯 正治療は進行することから，筋力の作用に対して歯の移動 だけでは咬合挙上に限界があると考え行った。

また，歯の移動速度と下顎頭のリモデリングの速度は同 じとはいえず，下顎頭のリモデリングは動的治療終了後も 継続していることから，矯正治療のみでは改善できない骨 格的問題点に対しては，歯冠修復，歯冠補緅により咬合高 径と咬頭勘合を確保させ，水平的拉よび垂直的下顎位を安 定させておく必要があると考えられた。

矯正治療に抢ける下顎位の誘導は, 診断時に治療目標と なる下顎位を設定し開始する。しかし動的治療期間中にお ける下顎位の誘導は, 干渉, 偏位, 適応を繰り返しながら, 顎口腔系の適応現象の続くなかで進行し, 生理的下顎位へ と誘導される。機能咬合獲得のためには, 生理的下顎位に おいて, 歯列の位置, 歯軸, ガイダンスなどが, 新たな干 渉などを作り出すことなく顎運動と調和する必要がある. よって矯正治療終了後には, 歯冠修復, 歯冠補綴の既往の ある歯やう蝕歯に対する治療を含めた歯冠形態の改善が必 須となる。

本症例は治療方針に制約のあるなかで，主訴に対する最 大限の改善を求めた結果, 治療期間は長期化してしまった。 しかし，顎運動に関わる筋群やリモデリングしにくい顎 関節などにおいては，良好な治療結果を得られたことから， 急速な変化よりもむしろ緩徐な変化のほうが, 生理的下顎 位と安定した機能咬合を獲得させ易かったと考えられた。

\section{症例2}

本症例の治療における特徵は, 下顎側方偏位の非外科的 治療に扔いて矯正治療単独で, 機能咬合を確立させた点で ある。

本症例は，顔貌所見において下顎が左方に偏位している ものの, セファロ写真分析においては下顎左方偏位以外大
きな問題点はなく, 著明な骨格的不正は認められなかった。 下顎の左方偏位は，右側での咬合干渉と咬合高径の左右差 によるものと考えられ，骨格の変形は比較的軽度であった。 また，処置歯や大きな歯の変形もみられないことから，矯 正治療単独で機能咬合を獲得させる方針となった。

この症例では動的治療途中に一旦は上下の正中線が一致 したが，17カ月間の動的治療期間で顎口腔系の機能に関 連したすべての器官が，適応しているとは考えにくい，そ こで, 下顎位や歯軸の安定しやすい状態を把握する目的で, ワイヤーをサイズダウンさせ咬合関係の適応を観察した.

その結果, 動的治療終了時は，下顎位はわずかに左方へ シフトした状態であった。これはその時点で得られた安定 しやすい顎位と理解できる。この下顎位で, 歯列弓形態, 歯軸, 歯冠形態, 顎運動が調和することで, 安定した機能 咬合を確立することができる.

安定した機能咬合は, 顎口腔系の機能時に生じる力のな かで確立できるものであり，人為的に与えられた咬合が必 ずしも適切とは限らない. 本症例からも一定期間, 機能時 の咬合を観察することで生理的下顎位との調和が確立され たと考えられた。

機能咬合を確立する上で, 生理的下顎位に安定させるこ とはもっとも重要な要素である。咬合干渉の除去や咬合高 径の調和により，下顎位は変化する。しかし，上下顎骨の 変形や顎口腔系の運動を司る筋群は, 成人の場合, 長い年 月をかけて形成され，ある程度の適応範囲を持つものの変 化を起こしにくい，よって，下顎側方偏位症例の非外科的 矯正治療に扔いて, 左右の対称性や正中線の一致など審美 的観点は, 適応できる生理的下顎位の範囲内に制限される. 矯正治療に扔いて生理的下顎位の範囲を超えた場合は，非 生理的下顎位となり，与えられた咬合は新たな干渉となっ て, 後戻りや新たな歯列不正を生じると考えられる.

矯正治療は, 歯の移動, 咬頭干渉, 下顎位の変化, 適応 現象を繰り返しながら, 患者が日常生活を営む中で進行し ていく. 各患者の不正咬合の状態は, 矯正治療によって変 化の起きやすい下顎位, 矯正治療によって変化の起きにく い骨格形態，矯正治療によって变化する咬合平面，歯列形 態, 歯軸, 矯正治療によって変化しない歯冠形態, これら の問題点が共存している．われわれにとって治療上で重要 な点は, 共存するこれらの問題点の有無と程度を的確に把 握し, 治療にかけられる期間, 治療効果の予測, 生体適応 反応を考慮することである，そのためには，主訴の把握， 適切な診察，多角的な資料の採得とその形態的分析や機能 的分析，などが必要不可欠となる。しかし，これらの資料 から診断を行い治療方針を決定して治療を開始したとして 
も，治療開始前に治療期間中の適応現象を的確に予測する ことは困難である.ゆえに, 患者固有の生体適応反応を常 に観察していくことが重要と考えられる.

\section{まとめ}

下顎側方偏位症例治療において, 審美的観点から顎偏位 の改善と上下正中線の一致は重要な課題である。 また, 機

\section{参考文献}

1) Sato, Lim CD, Miyagawa $Y$, Kim H, Akimoto $S$, Kim HY : The development of openbite as a result of posterior discrepancy and its treatment approach using multiloop edgewise arch wire. The International Journal of the MEAW Technic and Research Foundation, $5: 5-16,1999$.

2）佐藤貞雄, 秋本 進, 松本 淳, 白数明義, 吉田淳三： MEAWを用いた矯正治療：104-114, 第一歯科出版 (東京), 2001.

3) Sato S, Yuyama N, Tamura K, Tamaki K, Hori N, Kaneko M, Sasaguri K, Lee M C-il, Onozuka M, Slavicek R : The masticatory organ, brain function,stress-relase, and a proposal to add a new category to the taxonomy of the healing arts : Occlusion medicine. Bu11 Kanagawa Dent Coll, 30 : 117-126, 2002.

4) Slavicek R. The function of stress management. In : The masticatory organ-function and dysfunction, Slavicek, R(Ed), Klosterneuburg,Gamma Medizinisch - wissenschaftliche Fortdungs - AG, 281-291, 2002.

5) Sato $S$, Slavicek R. Bruxism as a stress management function of the masticatory organ : Bull. Kanagawa Dent Coll , 29: 101-110, 2001.

6) Guile, M.N. and McCutcheon, N.B : Prepared responses and gastric lesions in rats. Physiol. Psychology, $8:$ 480-482, 1980.

7) Vincent, G.P. Pare, W.P.D. and Prenatt, J.E : Aggression, body temperature, and stress ulcer. Physiol. Behavior, 32 : 265-268, 1984.

8) Glavin, G.B. Tanaka, M. Tsuda, A. Kohno, Y. Hoaki, Y. and Nagasaki, N : Regional rat brain noradrenaline turnover in response to restraint stress. Pharmacol. Biochem. Behav, 19: 287290,1983

9) Gomez FM, Giralt MT, Sainz B, Arrue A, Prieto M, Garcia VP : A possible attenuation of stress induced increases in striatal dopamine metabolism by the expression of non-functional masticatory activity in the rat. Eur J Oral Sci , 107 : 461-467, 1999.

10) Areso MP, Giralt MT, Sainz B, Prieto M, Garcia Vallejo P, Gomez FM : Occlusal disharmonies modulate central catecholaminergic activity in the rat. J Dent Res , 78 : 1204-1213, 1999.
能咬合の獲得は, 咀嚼, 会話, 呼吸, 審美, 姿勢維持など の機能に加え，アロスタシスの維持として必須である.

この2つの条件を各患者に構築するためには, 臨床診査, 診断資料を採得し, 分析することによって, 問題点を明確 にし，問題点の解決策を治療目標とする必要がある。さら に，時間軸に沿った生体適応反応を考慮した治療目標が重 要である.

11) Tsuda A, Tanaka $M$, Ida $Y$ et al : Expression of aggression attenuates stress- induced increases in rat brain noradorenaline turnover. Brain Res, $22: 90-98,1989$.

12）津田 彰, 他：ストレス曝露中の攻撃性の表出と脳内ノル アドレナリン代謝. 精神薬療基金研究年報，20：90-98, 1989.

13) Tanaka T, Yoshida M, Yokoo H, Tomita M, and Tanaka M : Expression of aggression attenuates both stress-induced gastric ulcer formation and increases in noradrenaline release in the rat amygdala assessed by intracerebral microdialysis. Pharmacol. Biochem. Behav, 59 : 27-31, 1998.

14) Tanaka M, Tsuda A, Yakoo H, Yoshida M, Mizoguchi K, Shimizu $\mathrm{T}$ : Psychological stress-induced increases in noradorenaline release in rat brain regions are attenuated by diazepam, but not by morphine. Pharmacol Biochem Behav, 39 : 191-195, 1991.

15) Tanaka $M$ : Emotional stress and characteristics of brain noradorenaline release in the rat. Ind Health , 37 : 143-156, 1999.

16) Kaneko M, Hori N, Yuyama N, Sasaguri K, Slavicek R, Sato S : Biting activity supress Fos expression in various region of the rat brain _ Further evidence that the masticatory organ functions to manage stress. Stomatologie ,101(7), 2004.

17) Hori N, Yuyama N, Tamura $K$ : Biting activities suppresses of stress-induced expression of corticotropin-releasing factor (CRF) in the rat hypothalamus. J Dent Res, 83, 124-128, 2003.

18）高階博文，伊藤由美，岩宮万里子，笹栗健一，佐藤貞雄 : 拘束ストレスの全身への影響と歯ぎしり様運動の効果. 神 奈川歯学, 40 (1) : 1-11, 2005.

19) McEwen BC : Protective and damaging effects of stress mediators. New England J Med , 338, 171-179, 1998.

20) McEwen $B C$ : The neurobiology of stress: from serendipity to clinical relevance. Brain Res, 886, 172-189, 2000.

21) McEwen BC : Mood disorders and allostatic load. Biol. Psychiatry, 54, 200-207, 2003.

22）石井秀典, 槻木恵一, 笹栗健一：アロスタシスにおける咀 嚼器官の役割．神奈川歯学，41（2）：125-134， 2006. 